\title{
Analysis Of Lead Level In Fish As a Water Bioindicator
}

\author{
RA. Hoetary Tirta Amallia ${ }^{1}$, Kevin Satria Wijaya ${ }^{2}$, Achmad Bagus Dhani ${ }^{3}$ \\ *e-mail: hoetary_uin@radenfatah.ac.id
}

\begin{abstract}
Biology study Program, Faculty of Science and Technology, UIN Raden Fatah Palembang, South Sumatera, Indonesia
\end{abstract}

\begin{abstract}
Cork Fish (Channa striata) and Baung Fish (Mystus)is a fish that has a high nutritional value and many produced from the Musi City Palembang River. Activities in the region can produce waste that can harm water environment such as industrial waste and domestic household waste. This research aims to determine the level of heavy metals lead $(\mathrm{Pb})$ in Cork fish (Channa striata) and Baung Fish (Mystus) originating from the Musi city of the river Palembang. Random sampling method on fish suppliers in the traditional market of Palembang by using the method of atomic absorption spetrophotometry. Based on the results of measurements made, heavy metal content of $\mathrm{Pb}$ Cork fish meat average of $0.1036 \mathrm{mg} / \mathrm{kg}$ and on average Baung fish meat 0.1425.As for the gills of the cork, the rate of Thymbalnya ranges between 0,0911$0,0953 \mathrm{mg} / \mathrm{kg}$ and in the gills of the fish range between $0,1117-0,1843 \mathrm{mg} / \mathrm{kg}$. There are heavy metal contaminants in the meat as well as the fish Cork (Channa striata) and Ikan Baung (Mystus) derived from the waters of the Musi River that is the city of Palembang where the heavy metal levels lead to the fish is higher compared with fish meat.
\end{abstract}

Keywords: Lead, Toxic, Water Pollution

\section{INTRODUCTION}

Indonesia is one of the largest archipelagic countries in the world and is one of the maritime countries that has a great potential for resources from the water because Indonesia directly borders on the free seas such as Indian Ocean and Pacific Ocean (Poesponegoro dkk, 2005; Sodik, 2014).

Kota Palembang, which is the capital city of South Sumatera Province, is one of the city which is overflowing by Musi River which reaches about 720 kilometers long and is the longest river that crosses Palembang City (setiawan dkk, 2013).

The more the economy of a city, the higher the growth of industry in the city that can trigger pollution source. Especially for the Musi own river. In the flow area of Musi River there are many industrial factories. Palembang Regional Environmental Agency mendata In 2011 there are about 24 industries that are on the outskirts of the Musi river such as oil refining, fertilizer factories, natural rubber processing, plywood and others. In addition, the household activities of the people living along the river Musi give great contribution to the inclusion of pollutant substances into the body of water and damaging the water biota (Trisnaini dkk, 2018).

In accordance with the theory by Atafar in 2010, stating that the activities of industrial, agricultural, and human activities are the causes of increasing the number of exiles or pollutants in the 
waters and damaging the environment (Emilia dkk, 2013).

One of the pollutant substances that is closely related to water pollution is heavy metals. Industrial waste and domestic waste will enter and carry into the river water flow and accumulate in the waters that can have a bad effect for the organism in it (Purnomo, 2014).

Fish that live in the irrigation that has been contaminated or already polluted becomes the main target of the pollution because the existence of heavy metals such as lead can accumulate in the body of fish. Heavy metals contained in the water as a habitat to turn fish will be absorbed into the fish's body through respiration in the gill, and into the gastrointestinal tract, or through the skin. Furthermore, the lead will bind the proteins in the tissues of the body, thus disrupting various physiological functions, the decline of the immune system, and can cause death in fish when the lead content in the fish has reached $188 \mathrm{mg} / \mathrm{l}$. It is a cell response to the chemical substances that interfere with the cell processes or sub-cells of living beings that exceed the normal limit causing direct death (connel and Miller, 1995; Palar, 1994; darmono, 1995).

Ikan Gabus and Ikan Baung is one type of fish that is produced by the waters of Musi City, Palembang and most often consumed by people other than good taste, also has a high nutrient content. Even some of the typical food of Palembang city will be processed by fish cork meat like Pempek, crackers, Tekwan, pindang and so forth. For Pindang cuisine it self most of Palembang residents cook fish without throwing the gills they believe that the taste will be better.As for the theory above, it is possible that $\mathrm{Pb}$ (lead) is likely to accumulate the most in the gills of fish.

Based on urian above, the purpose of this research is to identify the content of lead heavy metals $(\mathrm{Pb})$ in fish Cork (Channa striata) and Ikan Baung (Mystus) originating from the waters of Musi City River, using the method of atomic absorption spetrophotometry.

\section{MATERIALS AND METHODS}

\section{a. Population and Samples}

Samples of research are meat and gills of Cork Fish (Channa striata) and Baung Fish (Mystus) derived from the waters of Musi City River of Palembang with random sampling method on fish supplier in the traditional market of Palembang.

\section{b. Working Procedure}

The metal element of $\mathrm{Pb}$ is released from the sample meat network by means of dry (abusing) at a temperature of $450{ }^{\circ} \mathrm{C}$. Metals in the ash subsequently tied in hydrochloric acid $(\mathrm{HCl}) 6 \mathrm{M}$ and nitric acid (HNO3) $0.1 \quad M$ sequentially. The resulting solution was further atomised using graphite furnace.The atomic elements of $\mathrm{Pb}$ interact with the rays of the $\mathrm{Pb}$ lamps. The interaction is an absorption of light that can be seen in the display (monitor) of the atomic Absorption spectrophotometer (Atomic Absorption spectrophotometer). The amount of light absorption is proportional to the concentration of metal elements $\mathrm{Pb}$ and.

\section{c. Data Analysis}

Result of Pengjian is presented in the form of frequency distribution table to see the spread of kontaminal heavy Metal lead $(\mathrm{Pb})$ in meat and fish gills.

\section{RESULTS AND DISCUSSION}

Table 1. Lead Heavy Metal $(\mathrm{Pb})$ in Cork Meat (Channa striata).

\begin{tabular}{|cc|l|}
\hline $\begin{array}{c}\text { Sample } \\
\text { Code }\end{array}$ & Concentration & $\begin{array}{l}\text { Reference } \\
\text { Value }\end{array}$ \\
\hline GA $_{1}$ & $\mathbf{0 , 0 9 9 2}$ & $\mathbf{0 , 3} \mathbf{~ m g} / \mathbf{k g}$ \\
\hline $\mathbf{G A}_{2}$ & $\mathbf{0 , 1 8 4 3}$ & \\
\hline $\mathbf{G A}_{3}$ & $\mathbf{0 , 0 4 8 9}$ & \\
\hline
\end{tabular}




\begin{tabular}{|ll|}
\hline $\mathbf{G A}_{4}$ & $\mathbf{0 , 0 5 2 7}$ \\
\hline $\mathbf{G A}_{5}$ & $\mathbf{0 , 1 0 6 9}$ \\
\hline $\mathbf{G A}_{6}$ & $\mathbf{0 , 1 3 0 1}$ \\
\hline
\end{tabular}

From the table above, it is known that the lead heavy metals in the meat of Cork (Channa striata) is the highest in the sample $\mathrm{GA}_{2}$ as much as 0.1843 $\mathrm{mg} / \mathrm{kg}$ And the lowest found in the sample $\mathrm{GA}_{3}$ as much as $0.0489 \mathrm{mg} / \mathrm{kg}$.

Table 2. Lead Heavy Metals $(\mathrm{Pb})$ in Cork's fish gills (Channa striata).

\begin{tabular}{|c|c|c|}
\hline $\begin{array}{l}\text { Sample } \\
\text { Code }\end{array}$ & Concentration & $\begin{array}{l}\text { Reference } \\
\text { Value }\end{array}$ \\
\hline $\mathbf{G I}_{1}$ & 0,0914 & \multirow{6}{*}{$0,3 \mathrm{mg} / \mathrm{kg}$} \\
\hline $\mathbf{G I}_{2}$ & 0,0953 & \\
\hline $\mathbf{G I}_{3}$ & 0,0911 & \\
\hline GI $_{4}$ & 0,0912 & \\
\hline GI5 & 0,0942 & \\
\hline GI $_{6}$ & 0,0946 & \\
\hline
\end{tabular}

From the table above, it is noted that the high lead metal level of the best Cork (Channa striata) is found in the $\mathrm{GA}_{2}$ sample of $0.0953 \mathrm{mg} / \mathrm{kg}$ and the lowest in the sample $\mathrm{GA}_{3} 0,0911 \mathrm{mg} / \mathrm{kg}$.

Table 3. Lead Heavy Metals $(\mathrm{Pb})$ in Baung fish meat (Mystus).

\begin{tabular}{|c|c|c|}
\hline $\begin{array}{l}\text { Sample } \\
\text { Code }\end{array}$ & Concentration & $\begin{array}{l}\text { Reference } \\
\text { Value }\end{array}$ \\
\hline $\mathbf{B} \mathbf{A}_{1}$ & 0,1643 & $0,3 \mathrm{mg} / \mathrm{kg}$ \\
\hline $\mathbf{B A}_{2}$ & 0,1998 & \\
\hline $\mathbf{B A}_{3}$ & 0,1456 & \\
\hline $\mathbf{B A}_{4}$ & $\mathbf{0 , 1 3 0 1}$ & \\
\hline $\mathbf{B A}_{5}$ & 0,1418 & \\
\hline $\mathbf{B A}_{6}$ & 0,1611 & \\
\hline
\end{tabular}

From the table above, it is known that the highest lead heavy metals in Baung fish (Mystus) are found in the $\mathrm{BA}_{2}$ sample of $0.1998 \mathrm{mg} / \mathrm{kg}$ and the lowest in the sample $\mathrm{BA}_{4}$ as much as 0.1301 $\mathrm{mg} / \mathrm{kg}$.

Table 4. Lead Heavy Metals $(\mathrm{Pb})$ in Baung Fish's Gill (Mystus).

\begin{tabular}{|c|c|c|}
\hline $\begin{array}{l}\text { Sample } \\
\text { Code }\end{array}$ & Concentration & $\begin{array}{l}\text { Reference } \\
\text { Value }\end{array}$ \\
\hline BI $\mathbf{1}_{1}$ & 0,1611 & \multirow[t]{6}{*}{$0,3 \mathrm{mg} / \mathrm{kg}$} \\
\hline $\mathbf{B I}_{2}$ & 0,1843 & \\
\hline $\mathrm{BI}_{3}$ & 0,1117 & \\
\hline $\mathrm{BI}_{4}$ & 0,1124 & \\
\hline $\mathrm{BI}_{5}$ & 0,1256 & \\
\hline $\mathrm{BI}_{6}$ & 0,1602 & \\
\hline
\end{tabular}

From the table above, it is known that the highest lead weight metals in the fish Baung (Mystus) level is in the sample $\mathrm{BI}_{2}$ as much as $0.1843 \mathrm{mg} / \mathrm{kg}$ and the lowest in the sample $\mathrm{BI}_{4}$ as much as 0.1124 $\mathrm{mg} / \mathrm{kg}$.

Table 5. Comparison of lead heavy metals levels in Cork fish meat (Channa striata) and Baung Fish (Mystus).

\begin{tabular}{|c|c|c|}
\hline No & $\begin{array}{c}\text { Pb Heavy metal } \\
\text { content in Cork } \\
\text { fish meat }\end{array}$ & $\begin{array}{l}\text { Pb Heavy metal } \\
\text { content in Baung } \\
\text { fish meat }\end{array}$ \\
\hline 1 & $0,0992 \mathrm{mg} / \mathrm{kg}$ & $0,1611 \mathrm{mg} / \mathrm{kg}$ \\
\hline 2 & $0,1843 \mathrm{mg} / \mathrm{kg}$ & $0,1843 \mathrm{mg} / \mathrm{kg}$ \\
\hline 3 & $0,0489 \mathrm{mg} / \mathrm{kg}$ & $0,1117 \mathrm{mg} / \mathrm{kg}$ \\
\hline 4 & $0,0527 \mathrm{mg} / \mathrm{kg}$ & $0,1124 \mathrm{mg} / \mathrm{kg}$ \\
\hline 5 & $0,1069 \mathrm{mg} / \mathrm{kg}$ & $0,1256 \mathrm{mg} / \mathrm{kg}$ \\
\hline 6 & $0,1301 \mathrm{mg} / \mathrm{kg}$ & $0,1602 \mathrm{mg} / \mathrm{kg}$ \\
\hline Average & $0,1036 \mathrm{mg} / \mathrm{kg}$ & $0,1425 \mathrm{mg} / \mathrm{kg}$ \\
\hline
\end{tabular}

From the comparison table of the lead heavy Metals $(\mathrm{Pb})$ of the cork fish meat (Channa striata) and Ikan Baung (Mystus) can be known that the lead rate $(\mathrm{Pb})$ in Ikan Baung (Mystus) is higher compared with the meat of the fish Cork (Channa striata). These comparisons can be seen from the chart below:

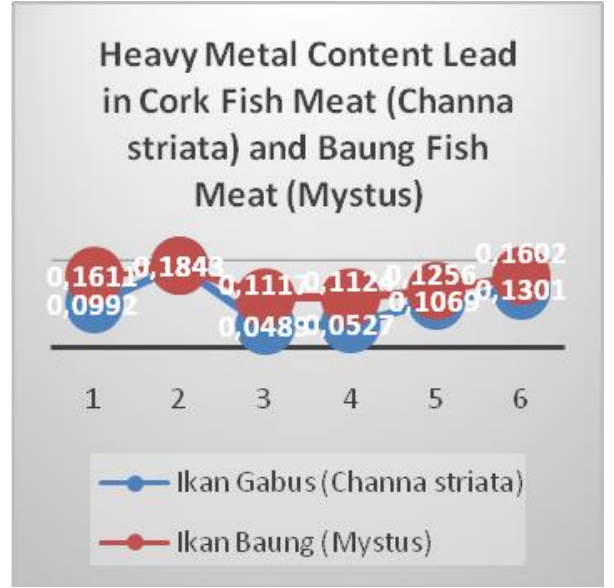

Picture 1. Lead Rate Comparation Chart

From the laboratory test results above is known that there is heavy metal content of the lead in meat and the gills of the cork fish (Channa striata) and Baung Fish (Mystus).

Fish is one of the bioindicators for the pollution of water biota waters in the waters. Biota that can be used as a heavy metal content in the flesh that crosses the threshold can be said that there has been pollution in the river water. Compounds 
and concentrations of pollutant substances will affect the level of heavy metals that are absorbed and distributed in fish (Sodik, 2014).

The lead metals that exist in the waters are usually tetravalen, resulting from the activity of microorganisms located at the base of the water (Mukono, 2005). Heavy metals that exist in the waters, will someday drop and settle on the base of the waters, form sedimentation and also cause people using water that contains heavy metals will have enormous opportunities to contaminated the heavy metals. Water containing heavy metals will be a toxic substance in the body of living creatures (Palar, 2008).

Fish meat that has been contaminated by heavy metals when consumed by society in its daily life should be an important concern. Although the heavy metal content in the fish meat is still in value that is still acceptable but the accumulated properties of heavy metals are noted that can cause a chronic toxic effect.

Bioaccumulation is the process of increasing the chemical concentration element in the body of living creatures according to the food pyramid. Heavy metals can also move from the environment to organisms and from one organism to another organism through the Food chain (Yalcin et al., 2008). The higher the level of the food chain occupied by an organism, the accumulation of heavy metals in the body is also increasing (Hananingtyas, 2017). According to the environmental of central java (2010), Therefore, human beings become main object that must be considered because the human being a center point or endpoint that will experience a large heavy metal accumulation in his body.

The inclusion of heavy metal lead into the human body can be through several pathways, namely through food, beverages, air and the secretion or penetration of the membrane or skin layer (Palar, 2012). Lead can be absored through inhalation of lead steam and polluted air particles as much as 100 to $350 \mathrm{~g} /$ day and $20 \mu \mathrm{g}$ (De roos, 2003).

One of the dangers of lead poisoning is damage to the nervous system because the nervous system is most sensitive to the toxic effects inflicted by lead and can cause acute intoxication. Delta-ALA will accumulate in the hypothalamus and protoporfirin in the dorsal nerve so that it can cause encephalopathy. The occurrence of neuropathy on the peripheral nerves due to lead toxicity caused by in elimination and nerve degeneration (Darmono, 2006). After that it will arise symptoms that are in the form of awkward, irritable, and decreased concept formation. When the baby has begun to be exposed by the New Testament, his influence on his psychological profile and his educational appearance will be seen at the age of about $5-15$ years.

In addition, lead (PB) can also cause anemia. This can occur due to a decrease in the synthesis of globin although there is no decrease in serum iron levels. Mild Anemia occurs accompanied by slight increase in levels of ALA (Amino Levulinic Acid). Hence anemia is considered as early symptom as the impact of lead poisoning (Robbins, 1995; Peter, 1994).

\section{CONCLUSION}

Lead heavy metal contaminants in the meat as well as the fish Cork (Channa striata) and Ikan Baung (Mystus) originating from the waters of the Musi River that envied the city of Palembang where heavy metal levels lead to the fish is higher compared with fish meat.

\section{REFERENCES}

Badan Lingkungan Hidup Kota Palembang. (2013). Laporan 
Analisis Kualitas Air Sungai dan Anak Sungai di dalam Wilayah Kota Palembang Tahun,2013.

Badan Lingkungan Hidup Provinsi Jawa Tengah. (2010). Laporan Kualitas Perairan Provinsi Jawa Tengah tahun 2001 sampai dengan 2010, Semarang.

Connel, D. W and Miller, G. J. (1995). Kimia dan ekotoksikologi pencemaran. Jakarta: Penerbit Universitas Indonesia.

Darmono. (1995). Logam dalam Sistem Biologi Makhluk Hidup. Cetakan I. Jakarta: Universitas Indonesia.

Darmono. (2006). Lingkungan hidup dan pencemaran: hubungannya dengan toksikologi senyawa logam. Jakarta: UI Press.

De Roos, F. J. (2003). Smelters and metal reclaimers. Occupational, Industrial, and Environmental Toxicology 2nd ed Philadelphia: Mosby, 388-97.

Emilia, I., Suheryanto, S., Hanafiah, Z. (2013). Distribusi Logam kadmium dalam air dan sedimen di Sungai Musi kota Palembang. Jurnal penelitian sains. 16, 2C.

Hananingtyas, I. (2017). Studi Pencemaran Kandungan Logam Berat Timbal $(\mathrm{Pb})$ dan Kadmium (Cd) pada Ikan Tongkol (Euthynnus sp.) di Pantai Utara Jawa, Jurnal Biotropic. Vol.1:4150.

Mukono, H. J. (2005). Toksikologi Lingkungan. Surabaya: Airlangga University Press.

Palar, H. (1994). Pencemaran dan Toksikologi Logam Berat. Jakarta: PT Rineka Cipta.

Palar, H. (2008). Pencemaran dan Toksikologi Logam Berat. Jakarta: PT Rineka Cipta.

Palar, H. (2012). Pencemaran dan toksikologi logam berat. Jakarta: PT Rineka Cipta.
Peter, O Neils. (1994). Environmental Chemistry, Second edition, Chapman \& Hall London, Journal Chemical education. 268.

Poesponegoro, M. D., Notosusanto, N. (2005). Sejarah Nasional Indonesia II. Edisi Pemutakhiran. Jakarta:Balai Pusaka.

Purnomo. (2014). Koefisien Korelasi Cramer dan Koefisien PHI Serta penerapannya. Yogyakarta: Universitas Negeri Yogyakarta.

Robbins. (1995). Buku Ajar Patologi I. Jakarta: EGC.

Setiawan, A. A., Emilia, I., Suheryanto, S. (2013). Kandungan Merkuri Total pada berbagai jenis ikan Cat fish di perairan Sungai Musi Kota Palembang. Jurnal Seminar Nasional Sains dan Teknologi V Lembaga Penelitian Universitas Lampung.

Sodik, D. M. (2014). Hukum Laut Internasional dan Pengaturannya di Indonesia. Jakarta: Rafika Aditiam.

Trisnaini, I., Kumalasari, T. N., Utama, F. (2018). Identifikasi Habitat Fisik Sungai dan Keberagaman Biotilik Sebagai Indikator Pencemaran Air Sungai Musi Kota Palembang. Jurnal Kesehatan Lingkungan Indonesia. Vol.17:1-8.

Yalcin, M. G., Narin, N., Soylak, M. (2008). Multivariate Analysis of Heavy Metal Contents of Sediments From Gumusler Creek, Nigde. Turkey. Environmental Geology. Vol. 54:1155-1163. 